\title{
Les Formes Élémentaires de la vie religieuse: passado, presente e futuro
}

EDWARD A. TIRYAKIAN"

\section{Resumo}

Neste artigo, o autor discute a obra de Durkheim dedicada às formas de religiosidade, analisando o contexto histórico de sua produção, sua influência hoje no campo da sociologia da religião e as perspectivas futuras diante das atuais tendências culturais no contexto global. Na primeira parte, tratando do passado, discute o complexo contexto cultural de As Formas, como um complemento à abordagem metodológica para o entendimento dessa obra proposta por Robert Alun Jones. Na segunda parte, explora o posicionamento atual de As Formas no campo da sociologia da religião, argumentando que a obra padece de um 'descaso deliberado' por boa parte dos sociólogos. Na terceira parte, volta-se para o futuro, buscando explorar o potencial de As Formas como fonte de teorização na sociologia da religião e, talvez, no pensamento social de modo geral. Apoiado em trabalhos recentes de Christian Smith, aponta diversas linhas de investigação que poderiam valer-se das análises de Durkheim e desenvolvê-las para o contexto atual.

Palavras-chave: Sociologia da religião. Sociologia da cultura. Efervescência. Crenças e ritos. Transcendência.

${ }^{*}$ Duke University (Estados Unidos) 


\section{Les Formes Élémentaires de la vie religieuse: past, present and future ${ }^{1}$}

\section{Abstract}

In this article, the author discusses Durkheim's work on forms of religious life, by analyzing the historical context of its production, its current influence in the field of sociology of religion, and future perspectives in the face of current cultural trends in the global context. In the first part, dealing with the past, he discusses the complex cultural context of The Elementary Forms, as a complement to the methodological approach proposed by Robert Alun Jones to the understanding of this work. In the second part, he explores the current position of The Elementary Forms in the field of sociology of religion, arguing that the work suffers from benign neglect among scholars. In the third part, it turns to the future, seeking to explore the potential of The Elementary Forms as a source of theorizing in the sociology of religion and perhaps as social thought tout court. Based on recent works by Christian Smith, he points out several lines of research that could rely on Durkheim's analyses and develop them for the current context.

Keywords: Sociology of religion. Sociology of culture. Effervescence. Beliefs and rituals. Transcendence

${ }^{1}$ Tradução: Fernando de Gonçalves e Regina Vargas. 
Sociologias, Porto Alegre, ano 19,no 44, jan/abr 2017, p. 38-71

\section{Introdução}

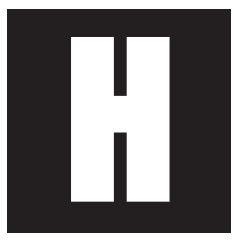

á mais de cem anos, às vésperas da Primeira Guerra Mundial, no ainda jovem século vinte, Émile Durkheim debatia-se, pode-se dizer, com uma intrincada questão da modernidade:

Há lugar, ainda, para a religião no mundo moderno?

E, em havendo, que forma é adequada à ordem social moderna?

Como sociólogo e livre pensador francês, sua questão poderia parecer "deslocada", ou bizarra, mas ele se vinha debatendo com ela havia muitos anos ou, pelo menos, desde que, graças aos esforços de seu sobrinho, Marcel Mauss, tivera acesso a Religion of the Semites ${ }^{2}$, de Robertson Smith (2002 [1894]). Poucos anos depois, Durkheim, o teórico que identificou a necessidade de complementar a teoria com evidências factuais, encontrara um valioso "conjunto de dados" reunido por Baldwin Spencer e F. J. Gillen, em sua monumental etnografia The Native Tribes of Central Australia (1899). Abrindo mão de seu estilo reservado, Durkheim dedicou uma laudatória resenha dessa obra em sua revista Année Sociologique (volume 3, 1900: 205 - 215), muito embora seu próprio conhecimento sobre pesquisa e análises antropológicas, inclusive com um foco em "totemismo" que tanto cativava a atenção de muitos de seus contemporâneos, fosse mais amplo do aquele encontrado na obra de Spencer e Gillen, por mais excepcional que fosse sua contribuição. ${ }^{3}$

\footnotetext{
${ }^{2}$ W. Robertson Smith, Lectures on the Religion of the Semites (1894), com uma nova Introdução, escrita por Robert A. Segal. New Brunswick, NJ: Transaction 2002.

${ }^{3}$ Eles deram seguimento à sua frutífera parceria, produzindo juntos: Across Australia (Spencer; Gillen, 1912) e, com a morte prematura de Gillen, Baldwin Spencer publicou sozinho o Native Tribes of the Northern Territory of Australia (1914). Em parte, a atração exercida pelo trabalho desses dois autores sobre um público mais amplo do que apenas o de antropólogos deveu-se ao extenso registro fotográfico que fizeram e à autenticidade de seu relato: "Toda a informa-
} 
Durkheim valeu-se muito de dados etnográficos, e suas interpretações teóricas integraram não só uma grande variedade de conhecimentos empíricos, dentro de um marco sociológico que ele e seus colaboradores vinham desenvolvendo há duas décadas, como também novos e ousados ensaios epistemológicos e axiológicos na esteira de Kant. Quando publicou As Formas Elementares da Vida Religiosa, não considerava completo o seu trabalho, porque a religião seria, por assim dizer, um invólucro, uma razão ontológica para a moralidade; sendo a religião fundamentalmente social, que novas luzes ela aportaria à ética? Durkheim lançou-se a uma exploração sociológica da ética. No entanto, a Primeira Grande Guerra viria a ser uma intrusão fatal em sua vida, e sua obra A Moral restou fragmentária - sugestivos prolegômenos, assim como O Capital de Marx e Economia e Sociedade de Weber ficaram como monumentos inacabados.

Ainda assim, As Formas tornou-se um fundamento para a sociologia da religião, gerando uma vasta e recente literatura subsequente que se expandiu enormemente nos últimos anos, deslocando a atenção dedicada, há cerca de uma geração atrás, aos primeiros clássicos durkheimianos: $A$ Divisão do Trabalho Social (Durkheim, 1997 [1893]) e Suicídio (Durkheim, 1951 [1897]). É preciso prestar reconhecimento a W.S.F. Pickering e Willie Watts-Miller, entre outros, que transformaram o Centro Britânico de Estudos Durkheimianos, da Universidade de Oxford, em um eminente canal de diálogo e de um volume considerável de publicações. Seria inútil

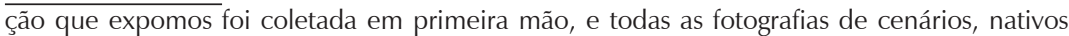
e cerimônias foram tiradas por nós. Convém agregar, ainda, que ambos fomos considerados como membros iniciados da Tribo Arunta" (Across Australia, p. 6). O privilégio da iniciação e de testemunhar "ritos sagrados", no entanto, não os levou a retratar os Arunta como "bons selvagens": "Deve-se ter sempre em mente que... as cerimônias nativas... são realizadas por selvagens uivantes e nus, que não têm habitação permanente, nem roupas, e não conhecem quaisquer implementos... nada confere uma impressão mais vívida de sua natureza selvagem do que a forma como tiram e usam seu próprio sangue (Across Australia, loc.cit). Durkheim também se valeu muito dos trabalhos do missionário e filólogo alemão Carl Strehlow, que traduziu os cantos e mitos Arunta. 
explorar esta literatura, e tampouco tentarei outra explanação sobre o próprio texto, pois presumo que os leitores estarão familiarizados com a maior parte desses. Irei ater-me a algumas partes de As Formas, com o objetivo de interpretar algumas condições societais da atualidade. ${ }^{4}$

O que farei na primeira parte, tratando do passado, será discutir o complexo contexto cultural de As Formas. Trago isso como um complemento à abordagem metodológica para o entendimento dessa obra no contexto intelectual da história da sociologia, proposta, há alguns anos, por Robert Alun Jones, ao descrever o clássico estudo de Durkheim.

À primeira vista, pode parecer surpreendente que Durkheim, um racionalista, vinculado a uma universidade racionalista, leal servidor da República cuja doutrina da laïcité havia triunfado sobre a Igreja Católica, viesse a exaltar o valor funcional da religião como essencial à existência humana. Antes de lidar com este paradoxo, precisamos relacioná-lo com um contexto cultural mais amplo, que tacitamente questionava o aparente triunfo da ordem social capitalista burguesa e seu individualismo econômico. Essa ordem social passara a ser vista, de uma forma inadequada, como "civilização", a qual indicava, implicitamente, o progresso material e moral do Ocidente, liberto das antigas amarras que ainda enredavam o resto do mundo. Arranha-céus, sistemas de transporte pneumáticos, metrôs, e outras modalidades de transporte como os automóveis propiciavam aos novos países urbanizados uma condição material "moderna", passível de contínuo aprimoramento tecnológico e científico, no âmbito de uma perspectiva geral de progresso material e moral. Quais seriam suas

\footnotetext{
${ }^{4} \mathrm{Fiz}$ isso em alguns ensaios reproduzidos em meu livro For Durkheim: Essays in Comparative and Historical Sociology (2009), especialmente: From Durkheim to Managua: Revolutions as Religious Revivals (De Durkheim a Managua: revoluções como renascimentos religiosos); No Laughing Matter: Applying Durkheim to Danish Cartoons (Não tem graça: aplicando Durkheim aos Cartoons dinamarqueses); e Collective Effervescence: Social Change, and Charisma: Durkheim, Weber and 1989 (Efervescência Coletiva - Mudança Social e Carisma: Durkheim, Weber e 1989).
} 
alternativas culturais? É neste ponto que devemos considerar um contexto cultural mais amplo, que reunia três diferentes elementos no ano em que Durkheim publicou As Formas: psicopatologia, teologia e as artes.

\section{2: Annus Mirabilis}

\section{Psicopatologia}

Durkheim não foi o único a ser atraído pelo totemismo australiano como a forma mais remota de vida religiosa. Os anos 1912-1913 também marcaram a publicação de quatro ensaios de Sigmund Freud que, reunidos, vieram a constituir Totem e Tabu (2011 [1913]). Em seu prefácio à atual edição, Kenny ${ }^{5}$ aponta que, para Freud, os aborígenes Arunta aportavam dados à psicanálise, que refutavam a atribuição, por Carl Jung, de forças não sexuais ao argumento freudiano da pulsão sexual como central para a psique humana. No início de 1912, Jung, que fora anteriormente saudado por Freud como "o ariano que viria a tirar a psicanálise de seu centro judaico europeu" ${ }^{\prime \prime}$, havia anunciado publicamente em Nova York divergências profundas entre as noções de cada um sobre a essência do inconsciente $^{7}$. Jung também havia elaborado sua própria perspectiva sobre a dinâmica da libido em seu Wandlungen und Symbole der Libido ${ }^{8}$.

\footnotetext{
${ }^{5}$ Referência ao novo prefácio de Robert Kenny à edição americana: Totem and Taboo. Resemblance between the Psychic Lives of Savages and Neurotics (1912-1913). Greentop, Missouri: Greentop Academic Press, 2011.

${ }^{6}$ Prefácio de Robert Kenny a Totem and Taboo, sem paginação.

${ }^{7}$ Ver Jung (2012) com Introdução de Sonu Shamdasan.

${ }^{8}$ Sua primeira edição em inglês é de 1916 (New York: Moffat, Yard and Company), com o título Psychology of the Unconscious: a study of the transformations and symbolisms of the libido: a contribution to the history of the evolution of thought, tradução de Beatrice M.Hinkle. A edição aqui referida (Jung, 2001) tem introdução de William McGuire, e um novo prefácio de Eugene Taylor. Esse trabalho marcou o rompimento definitivo da relação entre os dois, pois Jung rejeitou o reducionismo sexual da psicanálise, passando a explorar os simbolismos do inconsciente coletivo que afloravam no Gnosticismo, na Alquimia e na Cabala, assim como, em outras civilizações, no Hinduísmo e no Budismo.
} 
Frente a esse desafio, Freud leu de antemão todos os escritos disponíveis e os debates acadêmicos sobre os povos australianos, como os trabalhos de Wilhelm Wundt, Andrew Lang e James Frazer. Ele fez, inclusive, referência esclarecida à polêmica entre Durkheim e Frazer com relação a totemismo e exogamia, indicando estar bastante familiarizado com as publicações de Durkheim no Année Sociologique (Freud, 2011, p.88). O que atraía Freud para o aparente "pavor ao incesto", central ao totemismo, era como os rituais de evasão - o horror ao incesto - entre "esses canibais pobres e desnudos" impusera um elevado grau de restrição a seus impulsos sexuais (Freud, 2011, p. 13). O comportamento dos povos primitivos, afastados milhares de milhas e milhares de anos dos centros da civilização moderna, mostrava-se surpreendentemente similar ao dos pacientes neuróticos de Freud, demonstrando a universalidade da libido sexual reprimida e do complexo edipiano, uma faceta sombria, irracional da natureza humana. Para Freud, sua excursão antropológica no reino do primitivo estabelecia "um vínculo entre os estudiosos de etnologia, filologia, folclore e ciências conexas, com a psicanálise" (Freud, 2011, p. 12).

\section{Teologia}

No mesmo ano de 1912, quando Freud e Jung tomaram caminhos divergentes com referência ao significado da religião no inconsciente, Ernst Troeltsch, teólogo, filósofo e amigo de Max Weber, em Heidelberg, publicou seu monumental Die Soziallehren des Christlischen Kirchen und Gruppen (A Doutrina Social da Igreja e dos Grupos Cristãos) ${ }^{9}$, que viria a tornar-se um clássico da sociologia da religião. O texto equipara-se à sombria avaliação de Durkheim da situação da modernidade em que

\footnotetext{
${ }^{9}$ Ernst Troeltsch, Die Soziallehren der christlichen Kirchen und Gruppen. Tubingen: Verlag von J.C.B. Mohr, 1912. A tradução para o inglês foi publicada em 1931, com o título The Social Teaching of the Christian Churches (Troeltsch, 1931).
} 
"... os antigos deuses envelhecem ou morrem e outros não nasceram" (Durkheim, 1995, p. 429). Para Troeltsch, neste ponto, a questão é se há lugar para uma ética cristã no tumulto de uma ordem social fragmentada.

Durkheim retraçou as origens da religião desde suas manifestações mais precoces, no contexto primitivo materialmente mais acessível do Norte da Austrália. Troeltsch, apoiando-se nos tipos ideais introduzidos por Weber, retraçou a evolução da doutrina social cristã até o século dezoito, desde seu início, com as primeiras comunidades cristãs. Ele não pretendeu desenvolver uma história eclesiástica, mas uma história da interação entre os valores éticos da cristianismo e seus contextos sociais e políticos, destacando, nessa trajetória, as principais formas de comunidade religiosa, especialmente as três formas de relação com o mundo, que Troeltsch identificou como as de igrejas, de seitas e de misticismo ${ }^{10}$. Cada uma dessas formas estava sujeita a um processo histórico e, no cenário contemporâneo (isto é, 1912), "estão contados os dias da forma pura de igreja de nossa civilização atual" (Troeltsch, 1931, p. 1008). No passado, os princípios cristãos haviam propiciado união e coesão, mas poderiam fazê-lo outra vez em um presente em que o dogma e o apoio do Estado já não estão disponíveis?

"Que outras formas de filosofia social cristã poderiam emergir para controlar as condições sociais do presente?" - indagava Troeltsch em sua conclusão. A mesma problemática foi colocada por Weber, ao concluir A Ética Protestante e o Espírito do Capitalismo, e por Durkheim, em As Formas Elementares. A questão permanece tão relevante em 2012 quanto o foi em 1912, embora o contexto tenha mudado.

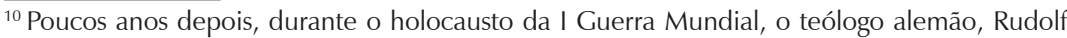
Otto publicou uma obra seminal sobre o misticismo, Das Heilige, traduzida para o inglês como The Holy: On the Irrational in the Idea of the Divine and its Relation to the Rational (Otto, 1923). A noção do ser sagrado experimentado como "o numinoso" é tanto "aterrorizante" quanto "fascinante": isso não se aplica igualmente à experiência na zona de combate da Primeira Guerra Mundial e à experiência primitiva do sagrado e do pavor do tabu?
} 
As Artes ${ }^{11}$

Em 1912, a arte moderna vivia um período de turbulência, com várias formas de arte de vanguarda gerando escândalos na pintura e nos palcos. A arte de vanguarda foi, na verdade, um instrumento contra as formas tradicionais de representação; em última instância, um palanque de oposição à mentalidade e à moralidade da sociedade burguesa e seus gostos para um refinamento civilizado. De que modo isso se conecta a Durkheim?

Em um primeiro momento, parece haver pouca convergência. O Année Sociologique relegou as artes a uma parte exígua de suas revisões bibliográficas, a minúscula Seção VII (Divers) que, no volume 12, o último publicado enquanto vivia Durkheim, contava apenas com 10 de 859 páginas ${ }^{12}$. Isso pode indicar a ambivalência de Durkheim em relação à arte (Pickering, 2000; Menger, 2000; O’Toole, 2002). Contudo, ainda que a estética não tivesse muito lugar em seu temperamento austero, ele reconhecia seu papel no apelo religioso, em especial na prática dos rituais religiosos (Durkheim, 1995, p. 383). Ele observa que, em uma tribo, os ritos têm como único propósito "cultivar alegria e bom humor". Entre os Arunta, tribo central para sua análise da religião, a prática ritual tem mesmo um aspecto de recreação, com os participantes "rindo e divertindo-se abertamente" (ibid., p. 384). Muitas vezes, os ritos religiosos comemorativos mesclam-se com entretenimento e todos podem participar, levando Durkheim a observar que o culto, embora busque outros objetivos "tem sido, simultaneamente, uma forma de recreação" (ibid., p. 385). Durkheim considerava a religião uma questão muito séria, embora admitisse, como observou Lukes (1972), que sua prática produzisse excessos,

\footnotetext{
${ }^{11}$ Para esta seção, utilizei material apresentado em meu ensaio Avant-Garde Art and Avant-Garde Sociology: 'Primitivism' and Durkheim ca. 1905-1913 (Tiryakian, 2009, pp. 167-87).

${ }^{12}$ Marcel Fournier (2006, p. 284) observou que "Mesmo em Année Sociologique, tanto na série antiga quanto na nova, a estética ocupava um lugar secundário... da arte primitiva e arqueologia, aos jogos, à literatura e à música".
} 
em geral oferecidos aos participantes como forma de alívio das mazelas do cotidiano, mesmo quando isso cobra manifestações eufóricas.

Durkheim não submeteu essa percepção a uma análise mais profunda, uma que pudesse ter explorado uma relação dialética entre a arte e a religião. Com um temperamento mais aberto a isso, Marcel Mauss "esperava que a estética se tornasse um ramo da sociologia" e, na Paris do pós-guerra, com seus alunos e amigos, como Georges Bataille, Marcel Griaule, Michel Leiris, Paul Rivière e outros, iria encontrar-se com "a vanguarda literária e artística" (Fournier, 2006, p. 284). Embora pareça auspicioso enveredar pelas ideias de Durkheim sobre o sagrado mediador entre a religião e a arte, via etnografia e vanguarda dos anos 1920 e 1930, vou restringir minha discussão ao cenário vanguardista do pré-guerra de quando Durkheim produziu As Formas Elementares.

A arte de vanguarda de 1912 produziu dois grandes abalos, quando não escândalos, junto ao público. Um deles foi na arte figurativa, com a ousada pintura de Pablo Picasso, Bordel en Avignon, cujo título foi reparado para Les Demoiselles d'Avignon. Ele chocou o grupo de pintores convidados para sua exibição inicial, tanto pela forma como retratava o seu objeto, quanto pela forma como representava as formas humanas [ver Figura 1]. Entre as diversas influências sobre a inovadora pintura de Picasso que marcou sua época, estavam máscaras ibéricas e máscaras africanas pré-históricas que encontravam-se em exibição no Museu de Trocadero. Ao vê-las, Picasso ficara, ao mesmo tempo, atraído e intimidado por sua aparência. Picasso e seu principal associado, Georges Braque, lideraram uma nova geração de artistas do movimento radical do "cubismo analítico" (com seu foco na análise das formas), o qual alcançou seu ápice em 1912, com o Nude Descending a Staircase de Marcel Duchamp [ver Figura 2]. Braque e Picasso enveredaram, então, por uma nova trilha do cubismo, que reunia objetos produzidos industrialmente, tais como linóleos, folhas de jornais e outros sobre a tela - a mistura da matéria inculta com 
a alta cultura. Essa nova incursão pelas colagens constituiu uma nova fase, a do "cubismo sintético", em que, em 1912, Picasso apresentou sua Natureza Morta com Cadeira de Palha. Em suma, o cubismo, que intimidou a arte tradicional e o modo como percebemos a realidade, foi um salto gigantesco da arte de vanguarda em 1912. Foi, em sua inspiração (particularmente no caso de Picasso), um retorno à experiência pré-histórica e primeva, em que as máscaras das civilizações primitivas, pré-ocidentais e arcaicas desempenharam um importante e complexo papel.

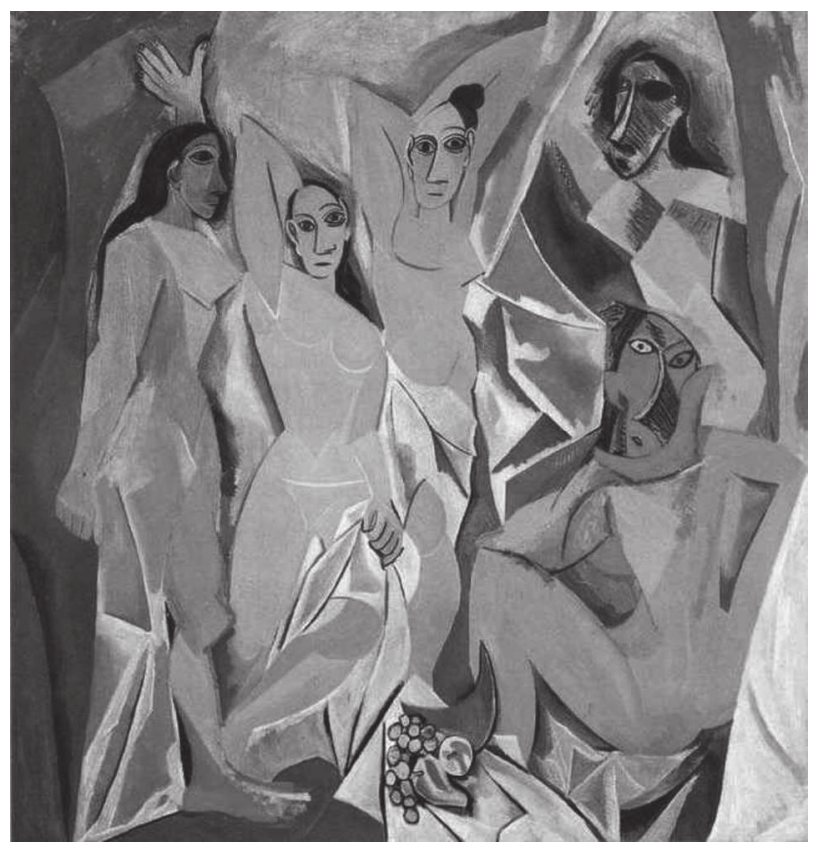

Figura 1 - Les Demoiselles d'Avignon

Fonte: Pablo Picasso, paintings, quotes and biography ${ }^{13}$

${ }^{13}$ Disponível em: $<$ http://www.pablopicasso.org/avignon.jsp $>$ 


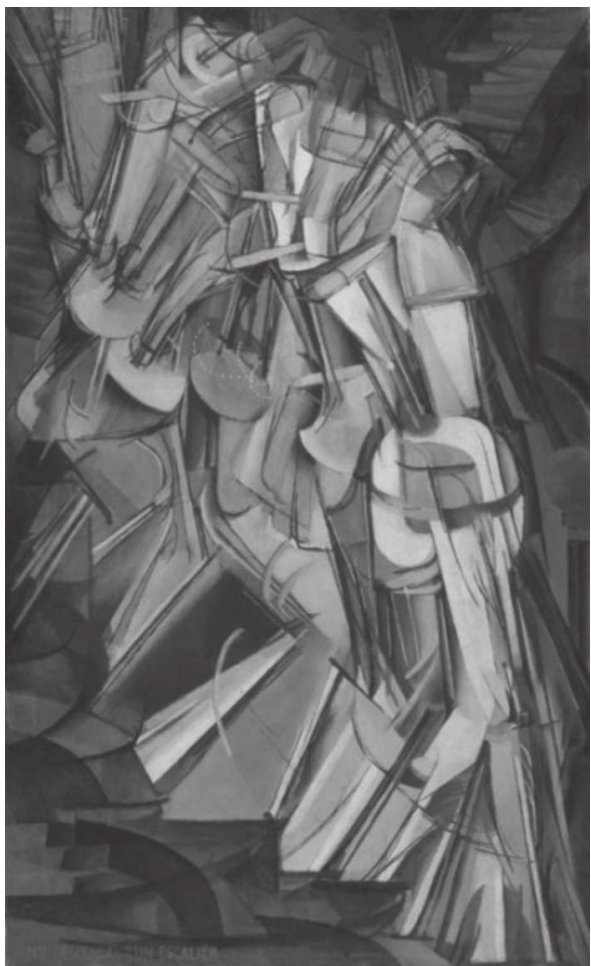

Figura 2 - Marcel Duchamp, Nu descendo uma escada №2, 1912 Fonte: Tate [online]. What's on. Room $3^{14}$

O apelo do primitivo, sua capacidade de provocar comoção no contexto europeu de início do século XX, estava presente, também, em outra modalidade de arte de vanguarda, uma que envolvia a expressão corporal: o balé (Tiryakian, 2009, pp. 180-182). Em 1909, Sergei Dia-

\footnotetext{
${ }^{14}$ Disponível em: <http://www.tate.org.uk/whats-on/exhibition/duchamp-man-ray-picabia/ explore-exhibition/room-3-movement>.
} 
ghilef trouxe, de Moscou, um grupo de artistas russos, criando com eles, em 1911, uma companhia independente, a Ballets Russes. Destacando-se como produtor teatral, Diaghilef reuniu bailarinos e bailarinas (Nijinsky, Markova, Pavolova), coreógrafos (Fokine, Massine), compositores (Ravel, Stravinsky) e cenógrafos (Bakst, Cocteau) de surpreedente talento. Em 1912, a encenação de L'après-midi d'un faune de Debussy, coreografada por Vaslav Nijinsky, escandalizou o público com a dança erótica final, executada pelo próprio Nijinsky, com um lenço que uma ninfa deixara cair. Escândalo ainda maior foi provocado pela encenação, em 1913, de Le Sacre du printemps (A Sagração da Primavera), de Igor Stravinsky, representando o primitivo sacrifício de uma jovem, e combinando a música desconcertante e agitada de Stravinsky com a chocante coreografia de Nijinsky. Tanto a música como a coreografia inspiravam-se em temas antigos, até mesmo arcaicos da "Rússia pagã" - como um crítico obervou posteriormente: "os pagãos no palco tornaram pagã a plateia" (Kelly, s.d.). Apesar, ou talvez em razão do impacto da nova forma, bruta, de representação dessa arte visual, que chocou a sensibilidade burguesa, o balé, como forma de arte, experimentou uma mudança de rumo definitiva ${ }^{15}$.

\footnotetext{
${ }^{15}$ Uma discussão mais completa da arte de vanguarda como contexto cultural deveria incluir a música. Penso na escala de doze tons, introduzida na composição por Arnold Schoenberg, e sua Harmonielehre (Teoria da Harmonia) de 1910. Entre seus alunos estavam Anton Webern, Alban Berg e John Cage. Enquanto Stravinsky causava tumulto em Paris, em 1913, com A Sagração da Primavera, Berg gerava clamor em Viena com sua première de Five Orchestral Songs on Picture Postcard Texts of Peter Aletenberg, conduzida por Schoenberg.
} 


\section{Entra em cena Durkheim}

Pode-se dizer que As Formas Elementares de Durkheim foram para a sociologia da cultura o que as Demoiselles d'Avignon de Picasso foram para a arte moderna. Cada uma delas constituiu uma complexa reelaboração criativa de materiais, que propiciava uma alternativa ao modo como víamos a realidade. E cada uma, à sua maneira, escandalizava. É oportuno, aqui, examinar como a indagação de Durkheim sobre religião e modernidade, que eu coloquei na introdução deste artigo, constituía, na verdade, um paradoxo. A publicação de As Formas desafiou o senso comum de que as sociedades mais primitivas estivessem centradas na religião, e sintetizou formas elementares de religião encontradas nos rituais. Isso escandalizou os crentes - duas categorias de crentes.

Por um lado, as aulas de sociologia de Durkheim e sua influência na Sorbonne provocavam não apenas a crítica de acadêmicos hostis ao pensamento coletivista inserido em sua produção teórica ${ }^{16}$, como também a de pensadores religiosos conservadores, particularmente aqueles leais à Igreja Católica ${ }^{17}$. Daquela perspectiva, As Formas não dava lugar à redenção do mundo pela misericórdia de uma divindade suprema e minimizava a experiência religiosa individual.

Por outro lado, a Terceira República defendida por Durkheim, com a exoneração do Capitão Alfred Dreyfus e a gestão de Emile Combes (1902-05) como Primeiro-Ministro, colocou o governo sob o firme controle da esquerda anti-clerical. O triunfo da esquerda culminou em 1905 com a promulgação da lei que estabelecia a separação entre a Igreja e o

\footnotetext{
${ }_{16}$ Para uma abordagem concisa dos críticos de Durkheim, ver Lukes, 1972, pp. 363-378.

${ }^{17}$ No último grupo, um crítico ferrenho foi Ferdinand Brunetière, editor da prestigiosa Revue des Deux Mondes, o qual se havia convertido ao catolicismo e fora afastado de sua cátedra na École Normale Supérieure, in 1905. Para uma discussão mais extensa sobre a ambivalência de posições em relação a As Formas por parte de intelectuais católicos e protestantes, ver Pickering, 2008.
} 
Estado e que levou ao fechamento imediato de 10.000 escolas vinculadas à Igreja. Durkheim, obstinado dreyfusard (defensor de Dreyfus), foi essencialmente um social-democrata e simpatizante do programa anti-clerical republicano (Durkheim, 1905). No entanto, considerava inadequado o intento de formar um regime republicano desprovido de toda religião; por muito que ele promovesse os méritos intelectuais do "individualismo" e o culto à humanidade, na esteira do caso Dreyfus (Durkheim, 1973[1898]), também percebia seus limites. Em última instância, seus limites estavam em manter o vínculo afetivo da população com o regime e as instituições de seu país.

O caminho para esse compromisso, ele viu confirmado, em toda parte, na religião totémica dos aborígines e, particularmente, nos rituais que reúnem todo o grupo gerando um estado de efervescência ${ }^{18}$. Precisamos fazer uma rápida digressão aqui, para examinar como aquilo que Durkheim discute no Livro Dois, Capítulo 7 de As Formas não só é fundamental para a teoria sociológica da religião, como também tem relação com a análise contextual que tenho discutido.

Jennifer Hecht chamou a atenção para um grupo interessante dentro da ampla coligação da esquerda: um considerável grupo de livres-pensadores anti-clericais que defendia o racionalismo e a ciência e que buscou usar a nova Sociedade de Antropologia para uma "veemente campanha contra a crença em Deus... com a intenção explícita de utilizar a jovem disciplina contra a religião, Deus e, especificamente, a Igreja Católica" (Hecht, 2003, p.1). Hostis a toda "metafísica" que pudesse impedir o igualitarismo, eles postulavam o materialismo científico e realizaram sondagens exaustivas ${ }^{19}$. Formaram uma "Sociedade de Mútua Autópsia" que

\footnotetext{
$\overline{{ }^{18} \text { Para perspectivas }}$ alternativas sobre "efervescência" em Durkheim, ver Ramp, 1998 e Allen, 1998.

${ }^{19}$ Hecht observa que algumas das técnicas utilizadas pelos governos para conhecer suas populações por meio de medições e estatísticas datam da época dos estudantes de antropologia livres-pensadores do século dezenove.
} 
envolvia um ritual bizarro (examinar o interior do crânio dos membros falecidos) com o objetivo de descartar a existência da alma. Era um retorno aos rituais e festivais convocados, durante a Revolução Francesa, pelos revolucionários que buscavam abolir os rituais católicos da vida cotidiana e substituí-los por um novo culto, a Teofilantropia ${ }^{20}$. Cem anos depois, esta última encontrou eco na "Antropossociologia" e na classificação das raças pela medição do índice cefálico. Depois de um meticuloso estudo dos postulados e dos fatos, Durkheim descartou a temática como seção do Année, porque "as bases científicas sobre as quais repousa este sistema são muito duvidosas" (Hecht, 2003, p. 239).

No capítulo em que concluía a discussão sobre as crenças totêmicas, Durkheim estendeu-se longamente para sustentar a tese de que a vida social se alterna entre a rotina cotidiana e os momentos criativos, quando há renovação, marcados por emoção, e mesmo fervor. Em poucas páginas, ele propôs a transfiguração, o modo como os indivíduos vivenciam as forças invisíveis, a ação de líderes carismáticos ${ }^{21}$ e grandes eventos na história em que "sob a influência da exaltação geral, vemos o burguês mais medíocre ou mais inofensivo transformar-se ou em herói ou em carrasco" (Durkheim, 1995, p. 213). É neste capítulo que ele faz a defesa da religião como uma força real que se exerce sobre os indivíduos, levando os que se encontram nesse estado de efervescência a viver de forma diferente do que em tempos normais. "Assim, o meio no qual vivemos nos aparece povoado de forças ao mesmo tempo imperiosas e de amparo, augustas e benfazejas, com as quais estamos contato" (Durkheim, 1995, p.214).

\footnotetext{
${ }^{20}$ Discuti essa questão em Tiryakian, 1988.

${ }^{21}$ Embora ele não tenha utilizado o termo "carisma", o que diz Durkheim (1995, p. 212) poderia perfeitamente ter sido dito por Weber.
} 
Não é necessário que me alongue em detalhes da discussão de Durkheim sobre a gênese do sagrado em sua interpretação dos relatos etnográficos de Spencer e Gillen sobre os rituais corrobori. Digo "interpretação", porque as emoções experimentadas pelos indivíduos Arunta ou, inclusive, pelos anônimos indivíduos que participaram de momentos como as Cruzadas, ou a Assembléia Geral de 4 de agosto de 1789 que aboliu o feudalismo, são interpretadas por Durkheim ${ }^{22}$ como valendo-se da força da coletividade para elevar (moralmente) os indivíduos a outro plano existencial. Nesse plano, observa, encontram-se tanto atos de heroísmo como de vilania.

Hecht aponta que Durkheim achou conveniente fazer referência à "singularidade mística dos ânimos populares e das revoltas públicas como aspectos da alma coletiva" (Hecht, 2003, p. 282). Poder-se-ia pensar que os surtos, como as situações de transgressão sexual durante momentos de efervescência coletiva observadas por Durkheim, foram o que o público francês apreciou em As Formas:

As paixões desencadeadas são de tal impetuosidade que não se deixam conter por nada.... Os sexos se juntam contrariamente às regras que presidem ao comércio sexual. Os homens trocam suas mulheres. Às vezes até uniões incestuosas, que em tempos normais são julgadas abomináveis e severamente condenadas, se realizam ostensiva e impunemente (Durkheim, 1995, p. 218) ${ }^{23}$.

O interesse de Durkheim com suas vívidas descrições dos registros de Spencer e Gillen não era o de alimentar a lascividade dos leitores burgueses de As Formas. Alguns dos leitores religiosos escandalizaram-se com sua interpretação de que a gênese do sagrado reside na união da

\footnotetext{
${ }^{22}$ Os Arunta, por não disporem de habilidades de escrita, não deixaram registros do que eles de fato experimentavam durante uma corrobori

${ }^{23}$ Utilizou-se, aqui, a tradução de Paulo Neves, da edição brasileira de As Formas (São Paulo: Martins Fontes, 2000) (N.T.)
} 
coletividade em momentos de exaltação, que então passam a integrar o simbolismo e a memória coletiva. Contudo, se Durkheim "secularizou" as noções tradicionais de Deus e da alma, do mesmo modo, ele também "sacralizou" o social e validou esses conceitos. Portanto, em última instância, a esquerda livre-pensante e materialista é que poderia escandalizar-se com a análise de Durkheim sobre a religião primitiva. Ao postular que a sociedade cria continuamente novos objetos sagrados - tanto praticamente divinizando como condenando outros ${ }^{24}$ - Durkheim fez uma pausa no Capítulo 7, Livro 2 da As Formas, para criticar a esquerda "radical" que queria rejeitar completamente a religião. Há, na sociedade moderna, muitos exemplos do proibido, cuja transgressão é experimentada como um sacrilégio:

Há, pelos menos, um princípio que os povos mais apaixonados pelo livre-exame tendem a colocar acima da discussão e a considerar como intangível, isto é, como sagrado: o princípio mesmo do livre-exame (Durkheim, 1995, p. 215).

Embora o exemplo do tabu da modernidade mencionado por Durkheim possa não ter sido o melhor, ele apontava que as antigas concepções de Deus e da "vida de sonhos" da coletividade estavam sujeitas a mudanças, mas que a sociedade como força moral sempre foi (Hecht, 2003, p. 289), e sempre será, de modo que a experiência do sagrado estará sempre presente. Durkheim estava, pode-se dizer, não só criticando os adeptos da fé religiosa e os novos materialistas seculares, mas respondia, igualmente, ao lamento de Nietzsche da morte de Deus.

Um escândalo respondia a outro.

Isso, de fato, fechava 1912 como um annus memorabilis, um ano memorável.

${ }^{24}$ Para ilustrar esse ponto, pensemos na quase divinização de Martin Luther King, Jr., de um lado, e na condenação universal de Hitler, de outro. 


\section{O Presente}

Tendo, até aqui, dedicado considerável atenção ao passado, voltemo-nos agora ao presente: como se posiciona As Formas Elementares hoje?

De certo modo, bastante bem. Em 2012, uma série de encontros acadêmicos celebraram o centenário de sua publicação e a obra é, sem dúvida, um clássico reconhecido tanto na sociologia da religião como na teoria sociológica. O largo uso das etnografias de Spencer e de Gillen por Durkheim manteve viva a memória do magnífico estudo empírico de aborígenes australianos realizado por eles. O epitáfio formulado por Spencer ao dizer adeus a seu falecido amigo Gillen e aos Arunta, em seu Prefácio ao Native Tribes of the Northern Territory of Australia, de 1914 - "[a] tribo Arunta, que infelizmente encontra-se hoje dizimada em números e irremediavelmente degenerada nos costumes ..." - deve ser reformulado (Spencer, 1914).

Os Arunta sobreviveram física e antropologicamente. Materialmente, eles sobreviveram graças à consciência pública da Austrália dos danos provocados no passado às populações indígenas e à política recíproca de "reconciliação" por parte do governo australiano e dos conselhos tribais indígenas. Podem-se observar evidências tangíveis desse avanço. $\mathrm{O}$ posto comercial onde os Arunta se reuniam no Território do Norte, Alice Springs, é hoje uma cidade próspera e moderna, onde é possível, até mesmo, encontrar, na livraria Red Kangaroo, um exemplar de As Formas Elementares!

O livro é também importante academicamente, como uma extensão dos trabalhos de Spencer e Gillen e de Durkheim, sendo uma atualização do conhecimento sobre os Arunta, com uma nova presença etnográfica no Território do Norte. Refiro-me ao notável trabalho de David $\mathrm{H}$. Turner, Professor emérito da Universidade de Toronto ${ }^{25}$. Assim como 
Spencer e Gillen puderam experimentar os rituais totêmicos por terem sido iniciados ${ }^{26}$, também Turner adquiriu conhecimento etnográfico sobre o "outro lado" da realidade - o chamado "Tempo do Sonho" (Altjeringa) - durante as cerimônias fúnebres, através de um processo interativo entre etnógrafo e informante (Turner, 1997). A iniciação, em 1986, o levou a pensar como, "e pelo menos tentar agir como um verdadeiro aborígene" (Turner, 1997, p.4).

Nesta e em outras duas obras, como Bellah observa com cuidado, Turner afirma que, ao experimentar a realidade do mundo através de sua música e seus instrumentos musicais, os aborígines são levados a uma filosofia social de "renúncia". Esta vai além do altruísmo: significa dar tudo o que têm a quem precisa. A renúncia faz a mediação entre a realidade física e a espiritual, fluindo incessantemente em direção ao outro (Bellah, 2011, p. 156). Para Turner, os aborígenes rejeitaram, social e espiritualmente, a tecnologia e excluíram as ideias de roubo, classe social e guerra, vivendo em paz por, possivelmente, milhares de anos. Assim como Durkheim percebeu que os modernos tinham muito a aprender com os aborígenes, também Bellah, ao comentar Turner, afirma que devemos considerá-los iguais, tendo muito a aprender com o igualitarismo dessa etapa primitiva de caçadores-coletores (Bellah, 2011, p. 174). Se não Durkheim, seu sobrinho Mauss, entusiasta da social-democracia e da "ideia de reciprocidade" (Fournier, 2006, p. 245), teria encontrado na filosofia social de "renúncia" dos Arunta um novo modelo para os cursos contemporâneos de [educação cívica] cidadania, como uma alternativa à cultura do individualismo econômico.

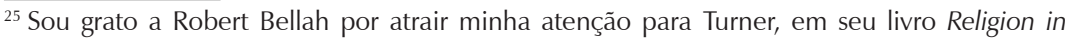
Human Evolution. From the Paleolithic to the Axial Age (Bellah, 2011).

${ }^{26}$ No Prefácio recém citado de Spencer, ele afirma com orgulho “... tanto o finado Mr. Gillen como eu mesmo fomos considerados membros plenamente iniciados da tribo Arunta" (Spencer, 1914, p. x).
} 
Em sua notável narrativa sobre a evolução da religião, Bellah, em grande medida, faz uso de As Formas, de Durkheim, seja de modo implícito ou explícito - por exemplo, com a noção de "efervescência coletiva" do ritual grupal que permite ao grupo experimentar uma realidade diferente e mais profunda (Bellah, 2011, p. 17). Ele segue, discutindo como os "mitos" e os rituais, nos estágios primevos da evolução cultural, estão estreitamente conectados, sendo os rituais bastante "elementares", mais resistentes à mudança do que os "mitos". Como demonstrar isso? Tacitamente seguindo Durkheim, Bellah busca dados antropológicos para identificar as origens da inovação cultural em grupos de caçadores-coletores. A maioria dessas populações foi absorvida - ou aniquilada - por agricultores e citadinos. Mas há dois grupos de caçadores-coletores que "podem estar mais próximos de nossa antiga tradição do que qualquer outra dessas sociedades" (ibid., p.138). O primeiro é o dos Arunta, e já mencionei brevemente a filosofia social que está incorporada em seus rituais.

O segundo caso de "Religião Tribal" apresentado por Bellah é o dos índios Kalapalo, do Parque Indígena do Xingu, no Mato Grosso, Brasil. Essa tribo tem sido exaustivamente estudada pela antropóloga americana Ellen Basso (professora emérita no Arizona) ${ }^{27}$. Assim como os Arunta, os Kalapalo foram dizimados por doenças como a gripe e o sarampo trazidos por forasteiros, e seu habitat tem sido alvo de desmatamento por criadores de gado. Contudo, sua população tem apresentado crescimento, de 110 pessoas, em 1968, para aproximadamente 362, há dez anos atrás. Do mesmo modo que o uso da música, conforme Turner, destacava-se no ritual Arunta, Basso observou o uso de flautas em rituais Kalapalo como significativos na comunicação social: tanto como manifestação de transformações agressivas de um ser poderoso quanto como um meio disponível às pessoas para controlarem essas forças (Basso, 2002).

\footnotetext{
${ }^{27}$ Além das referências em Bellah, 2011, também utilizei informações de Povos Indígenas no Brasil, "Kalapalo" Disponível em: (http://pib.socioambiental.org/en/povo/kalapalo)
} 
A riqueza e a complexidade dos rituais certamente proporcionariam a Durkheim uma segunda "coleção de dados", bem como o sistema de crenças em termos das quais os Kalapalo classificam as coisas, inclusive o que pode ser comido, e por quem. Durkheim e Mauss teriam observado a crença Kalapalo de que a aparência externa de alguém é indicativa dos seus sentimentos íntimos, de modo que a beleza física, adquirida pela observância de uma dieta prescrita, é sinal de beleza moral. Também o lado normativo das relações dos Kalapalo teriam atraído sua atenção. O ideal de comportamento é chamado ifutisu, que Basso vê como um conjunto de postulados éticos que distingue os Kalapalo e seus vizinhos imediatos dos demais seres humanos. O ifutisu contém duas principais regras comportamentais: (1) ausência de agressividade pública, tal como abster-se de provocar situações que façam os outros sentirem-se desconfortáveis; e (2) a prática de generosidade, tal como hospitalidade e disposição a compartilhar posses materiais. Basso observa que a conformidade a esse padrão comportamental, na visão dos Kalapalo, é fundamental para a viabilidade de sua sociedade (Basso, 2002).

Não sei se Turner e Basso, realizando suas pesquisas etnográficas a milhares de quilômetros uma da outra, chegaram a comparar seus achados sobre sociedades "primitivas" de caçadores-coletores. Evidentemente, podem-se encontrar muitas diferenças culturais na experiência histórica, ambiente ecológico e composição genética das tribos. Contudo, embora nem os Arunta nem os Kalapalos sejam caracterizados pelos etnógrafos como "bons selvagens" e tampouco como "bárbaros", eles se situam firmemente no primeiro degrau da escala evolutiva do desenvolvimento social e cultural. Comungo do pensamento de Bellah de que "a cultura aborígene é, em muitos aspectos, superior à nossa" (Bellah, 2011, p.156), tanto por não se engajar em guerras de expansão contra tribos vizinhas, como por seu sistema normativo que regula a conduta social na solidariedade social. 
Os relatos originais de Spencer e Gillen mencionaram vários exemplos de conflitos individuais, para ser exato, mas havia meios institucionalizados de minimizá-los, e isso certamente segue sendo assim hoje. Durkheim não poderia ter lido esses relatos sem ter ciência dos conflitos cotidianos na sociedade arcaica, mas, se não enfatizou esse fato, foi por estar muito consciente dos crescentes conflitos na sociedade moderna.

Embora, em As Formas Elementares, ele tenha enfatizado as funções favoráveis da religião em crenças e rituais que integram uma sociedade moderna complexa, Durkheim também reconheceu o "lado sombrio" que brota na história, quando o fervor religioso pode dar lugar ao extermínio ou apropriação insanos "do outro". No entanto, desenvolveu-se na sociologia da religião americana um infundado repúdio pelo "funcionalismo", beirando a um tabu. Talvez por atribuir-se uma culpa tácita a As Formas Elementares da Vida Religiosa, por associação a esse repúdio, a obra raramente figura nos programas dos cursos de sociologia da religião. O foco da pesquisa empírica está normalmente nas sondagens, com uso de técnicas estatísticas sofisticadas, e produção de best-sellers como as obras de Robert Putnam e David Campbell's American Grace (2010) e de Mark Chaves, American Religion (2011). Estes trabalhos renderam dados interessantes, particularmente os dados intergeracionais relativos às tendências da afiliação religiosa, mas não cabe aqui discuti-los. Devemos ter em mente que, ao escrever As Formas, Durkheim tinha tanto um propósito científico quanto um propósito moral. Seu uso de dados etnográficos qualitativos seguiu-se à utilização de dados estatísticos quantitativos (em seu estudo de Suicídio) para chegar às camadas mais invisíveis da organização social, essencialmente à solidariedade social. Essa coesão interna da sociedade moderna não deve assumida como dada; a situação atual nas chamadas sociedade avançadas mostra que as preocupações de Durkheim com o destino da Terceira República Francesa são praticamente as mesmas nossas, 100 anos depois. 
E, talvez, o pior ato de injustiça, pelo menos no plano simbólico, seja o fato de que, no ano do centenário, a estimada Année Sociologique de Durkheim, orgulho e júbilo dele mesmo e de sua brilhante equipe, não só não fazia menção a As Formas, como, em vez disso trazia um artigo sobre ... Weber e antropologia! (Löwy; Varikas, 2012) ${ }^{28}$.

Em termos do "panorama geral" da modernidade, o que tem dominado o discurso na presente geração, além das sondagens em larga escala, são os vários estudos que trabalham dentro do marco de referência de uma "Era Axial". O conceito, inicialmente associado ao filósofo existencial Karl Jaspers, foi posteriormente desenvolvido ao longo de um quarto de século por Shmuel Eisenstadt e pesquisadores associados a ele. Esse marco tentava produzir uma mudança importante na narrativa ocidental do desenvolvimento do mundo, introduzindo um momento histórico de "partida" em que, em várias regiões do mundo (especialmente, mas não exclusivamente, na Ásia e no Mediterrâneo Oriental), visões cognitivas e normativas de uma outra realidade que interagia com contexto terreno, surgiram para alguns indivíduos (como Buda, Confúcio, Mencius, os pré-socráticos, Platão).

Em seu conjunto, essas visões e ensinamentos formaram um amplo pivô "Axial" o qual veio a proporcionar diferentes trajetórias de modernidade, embora não de forma linear. A mais abrangente abordagem contemporânea da modernidade da Era Axial consiste em um volume coletivo organizado por Robert Bellah e Hans Joas (2012). Como ler essa obra em relação ao que Durkheim procurou fazer?

De certo modo, Durkheim poderia levantar questionamentos metodológicos com relação ao conceito de "Era Axial" e sobre em que medida este subsume ou substitui a sociedade como um sistema de forças ativas, que é, ao mesmo tempo sofisticado e confere à humanidade seus atributos

\footnotetext{
${ }^{28}$ Quando preparei a conferência que deu origem a esse artigo, apenas o primeiro número de 2012 da L'Année estava publicado. Fui informado, posteriormente, de que a segunda edição do ano trazia, sim, referência a Durkheim.
} 
distintivos - recordemos aqui sua epígrafe em grego com o conceito de polis de Aristóteles na página de rosto de De la Division du Travail Social (A Divisão do Trabalho Social) e seu parágrafo de conclusão em Les Formes.

Deixando de lado o ceticismo metodológico, Durkheim poderia encontrar pontos em comum com o conceito de Era Axial na acepção que um dos organizadores do volume denomina "a era da emergência da ideia de transcendência". Em seu ensaio introdutório ao The Axial Age and its Consequences, Hans Joas explica seu uso do termo "transcendência", presumindo que todos os colaboradores no debate sobre a Era Axial adotam suposições e atitudes em relação à religião (Joas, 2012). Ele aponta diferentes perspectivas no debate, decorrentes de uma ambiguidade fundamental - se a "perda da transcendência" é interpretada como um perigoso retrocesso ou um apelo profético para uma forçosa libertação rumo à modernidade, ou dentro de uma esfera ampla em que diferentes versões podem ser contrapostas ("Atenas ou Jerusalém?"). Há outra ambiguidade não mencionada por Joas: ao procurar transcender a demarcação temporal do centrismo ocidental, os secularistas optaram por utilizar "E.C." e "A.E.C" para atenuar a noção de "A.C.-D.C" de ruptura do tempo histórico ${ }^{29}$. Isso, no entanto, mantém o mesmo corte abrupto e deixa de fora tanto o calendário temporal da Era Axial como o das civilizações não-Axiais ${ }^{30}$.

Apesar da ambigüidade tanto da "Era Axial" como de sua concomitante "transcendência", os debates relativos ao seu terreno religioso e anti-religioso oferecem muitos elementos para novas reflexões sobre história e mudança social, as quais, afinal, constituíam um propósito subjacente a As Formas de Durkheim. Joas, que transita bem entre a socio-

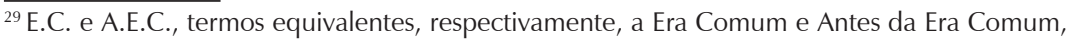
são usados como substitutos aos termos com conotação religiosa A.D. (Anno Domini), A.C. (Antes de Cristo) e D.C. (Depois de Cristo). No entanto são igualmente baseados no calendário Gregoriano, referindo-se aos mesmos períodos e corte históricos.

${ }^{30}$ Abordei esta questão há alguns anos, em meu artigo, Time to Change the Calendar? Sacred and Secular Problems of Crossing the Millennium (Tiryakian, 2001).
} 
logia da religião e a filosofia, aponta, seguindo Jürgen Habermas ${ }^{31}$, que Jaspers entendia a nova perspectiva da Era Axial como promotora de um diálogo entre a filosofia e as religiões pós-Axiais, assim como entre as religiões. O contexto para tal diálogo bem poderia ter sido o das rupturas e carnificinas das guerras mundiais do século XX, e a ênfase de Jaspers na transcendência - "historicismo existencialmente transformado", como diz Joas - não põe um ponto final no debate.

Durkheim iria encontrar no conceito de "transcendência" um meio de conectar sua análise da religião "primitiva" dos aborígenes com aquilo que o preocupava em relação à sua própria sociedade contemporânea. As formas elementares da vida religiosa são representações da "transcendência" e, tal como ele sublinhou, não existe "falsa" religião, de modo que ele acolheria a afirmação final de Joas:

Portanto, minha ênfase nas dimensões religiosas do debate da Era Axial não pretendeu desmerecer... mas antes servir de incentivo a conectar deliberadamente a pesquisa empírica sobre a história da religião com as questões mais fundamentais de nossas orientações no mundo contemporâneo (Joas, 2012, p. 24 ).

A transcendência é uma noção plena de significado, que relaciona Durkheim com o passado e com o presente. Com o passado, em termos dos múltiplos aspectos do contexto de As Formas. Na psicologia / psicopatologia, Freud e Jung realizaram análises do inconsciente oculto que transcende a racionalidade da vida cotidiana. A arte de vanguarda procurou transcender nossa visão e percepção da realidade de maneiras radicalmente novas. Com Troeltsch, a teologia retornou à igreja primitiva, buscando transcender as divisões da cristandade, que se desenvolveram a partir da diferenciação da comunidade original de fiéis. Uma forma mais

\footnotetext{
${ }^{31}$ Ver Habermas, 1987. Habermas utiliza a obra de Jaspers, A situação espiritual de nosso tempo (Die geistige Situation der Zeit) de 1931, como estímulo aos colegas que convidou (em 1978) para fazerem um diagnóstico da situação daquele momento.
} 
radical de transcendência religiosa foi captada não no memorável ano de 1912, mas pouco depois, em 1917, na obra Das Heilige (A Ideia do Sagrado) de Rudolf Otto, com sua abordagem fenomenológica dos sentimentos e emoções do tipo "numinoso" e do "mysterium tremendum", pela qual a moralidade é parte essencial da experiência religiosa.

Hoje, no ocidente secularizado e higienizado, o clássico de Otto sofre de descaso deliberado, embora a experiência religiosa que buscou descrever pareça ainda estar presente em seitas religiosas, cristãs e não-cristãs. Em meio à Primeira Guerra Mundial, Durkheim talvez não tivesse tido a oportunidade de ler Das Heilige, mas, acredito eu, sua não-declarada abordagem fenomenológica à interpretação da religião dos aborígines o teria levado a ver o "numinoso" como uma realidade apreendida, o "numinoso" da sociedade invisível experimentada pelos indivíduos.

Se voltasse, Durkheim encontraria muito trabalho para expandir sua sociologia da religião tanto na pesquisa empírica quantitativa que passou a predominar, como naquela mais qualitativa, histórico-comparativa dos seguidores da Era Axial. Ele, sem dúvida, faria eco às palavras finais de Robert Bellah (2012) no último capítulo de The Axial Age and Its Consequences, no qual este último invoca o legado na evolução da teoria como aprimoramento cognitivo e como intensificação normativa ou ideológica. Bellah afirma:

Eles proporcionaram as ferramentas intelectuais para esforços de reforma e para esforços de dominação. É um grande legado... Ainda assim, é um legado de potencialidades explosivas para o bem e para o mal. Propiciou-nos a grande ferramenta da crítica. Como vamos utilizá-la? (Bellah, 2012, p. 465) 


\section{O Futuro}

Para onde ir, agora? As Formas Elementares da Vida Religiosa terá esgotado seu potencial como fonte de teorização na sociologia da religião e, talvez, no pensamento social de modo amplo? Pode seguir tendo espaço na estante como um clássico, mas poderemos revolver suas brasas para torná-la "efervescente" outra vez? Uma iniciativa recente parece estar a ponto de prover novos impulsos a este grande trabalho.

Christian Smith, diretor do Centro de Estudos de Religião e Sociedade da Universidade de Notre Dame, é uma das principais figuras americanas da sociologia da religião. Ele apoiou-se na "epistemologia social" de Durkheim para abordar questões muito básicas, "elementares", tais como "o que é uma pessoa?", e como uma ontologia social realista nos instrui sobre a dignidade de todos os seres humanos como alternativa ao atomismo individualista do individualismo liberal? (Smith, 2010). Um diálogo bastante frutífero deve resultar entre o trabalho de Smith e grande parte da análise de Durkheim sobre a religião e o individualismo (em seus ensaios $O$ individualismo e os intelectuais e $A$ dualidade da natureza humana) (Durkheim, 1973a; 1973b).

Mais a propósito, para o momento, é o ensaio de Smith que revê o campo da sociologia da religião (Smith, 2008). Depois de discutir dois paradigmas - o empirismo positivista e o interpretativismo hermenêutico - que geraram um grande volume de pesquisas atuais, ele procura ir além das já bem exploradas características do cotidiano, avançando para áreas emergentes da experiência social (Smith, 2008, p. 1563). Que áreas da sociologia da religião ainda carecem de mais estudos e podem gerar ideias originais em estudos e pesquisas?

O primeiro ponto mencionado por ele são as crenças. As pesquisas de tipo survey só indiretamente conseguem informar sobre as crenças das pessoas. Smith argumenta que a maior parte das perguntas inseridas 
em questionários de pesquisas sobre "crença em Deus" não consegue captar a essência das crenças das pessoas, e esses instrumentos informam muito pouco sobre por que ou como as pessoas se vinculam a uma determinada organização religiosa e não a outra. Smith indica um estudo que mostra como as surveys podem melhorar a avaliação da religiosidade, levando mais a sério as verdadeiras crenças de determinados grupos religiosos (Smith, 2008, p.1564). Entretanto, uma parte considerável de As Formas Elementares é dedicada precisamente à análise das crenças religiosas; há muito a ganhar com uma nova perspectiva para a pesquisa de sondagem decorrente da releitura de Durkheim e de sua aplicação às estruturas das organizações contemporâneas, em termos das crenças subjacentes à adesão a essas estruturas.

Uma segunda área que Smith considera merecedora de mais estudos é "o papel do corpo na religião". Como ele observa: "os corpos encarnam parcialmente as crenças religiosas e vivenciam as práticas religiosas" (Smith, 2008, p.1565). Smith segue, discutindo o quão integralmente a religião se relaciona com o corpo, e, ainda assim, a pesquisa contemporânea em sociologia da religião mal tocou essa questão. Smith não está a propor um programa de pesquisa específico, mas sugere que o estudo do corpo em relação ao sagrado poderia enriquecer muito nossa compreensão sociológica da religião. Neste ponto, mais uma vez, eu gostaria de apontar, há chance de um produtivo diálogo entre Durkheim e os pesquisadores contemporâneos da sociologia da religião e da sociologia cultural. Pois Durkheim chamou a atenção para a importância do corpo em boa parte da religião totêmica, por exemplo, na identidade pessoal e coletiva das tatuagens.

A trilha de Durkheim foi seguida, depois da Primeira Guerra Mundial, pelo próprio trabalho seminal de Mauss sobre as "técnicas do corpo"(Mauss, 1935). Tanto Durkheim como Mauss teriam grande interesse em ver como as tatuagens migraram dos primitivos arcaicos aborí- 
gines para ambientes urbanos modernos e burgueses ${ }^{32}$ ! Trata-se de uma anomalia da modernidade que demanda pesquisa empírica séria e teorização, tais que possam intensificar ainda mais a necessidade de diálogo entre os patronos de As Formas de Durkheim e a pesquisa contemporânea avançada em sociologia da religião.

Embora Smith discuta outras áreas promissoras para novas pesquisas em sociologia da religião, aqui precisamos considerar só mais uma: as emoções (Smith, 2008, 1566). As emoções tornaram-se um foco de interesse legítimo dos sociólogos, e até mesmo atraíram estudiosos para uma nova seção da Associação Americana de Sociologia. Apesar disso, Smith considera que o tema não foi incorporado às correntes principais da sociologia da religião que preferem concentrar-se nos aspectos mais "nobres", organizacionais, políticos ou econômicos, dessa disciplina. Ainda assim, como Durkheim percebeu claramente ao explorar o material etnográfico sobre os Arunta e ao alinhar os momentos de "efervescência coletiva" aos momentos históricos quando são gerados e realizados novos ideais, a vida religiosa é vivenciada através de emoções, e não só pela consciência. Outra vez, este é um elo importante em um possível diálogo entre As Formas Elementares e a sociologia da religião.

Encerro aqui esta discussão sobre o trabalho de Smith, como uma possível abertura a um futuro de renovado interesse na magnum opus de Durkheim. Talvez, mais do que um elo com a sociologia da religião, esse seja um elo com o próprio pensamento social. Isso porque Durkheim, um racionalista e fervoroso defensor da democracia moderna, tinha plena consciência da fragilidade de uma democracia sem vínculo afetivo. O vín-

\footnotetext{
${ }^{32}$ De sua imagem antissocial e inconformista nos anos 1960, a tatuagem tornou-se uma indústria multibilionária, com uma parcela estimada de $1 / 3$ de todas as pessoas norte-americanas com menos de 25 anos e dois quintos das com idade entre 26 e 40 usando tatuagens. A prática tornou-se dominante, não só entre equipes esportivas, mas também entre uma grande diversidade de celebridades. Ver Hoag Levins, "The Changing Cultural Status of the Tattoo Arts in America" em: http://tattooartist.com/history.html.
} 
culo afetivo demonstrado em 1898 pelos dreyfusards se havia já dissipado em 1912. Ao aprofundar-se no passado pré-histórico, Durkheim buscava ferramentas para reavivar as chamas do compromisso com uma ordem democrática. A solidariedade propiciada pela guerra, em 1914, com a union sacrée, quando esquerda e direita uniram-se na Assembleia Geral, foi transitória. Durkheim faleceu antes do fim da guerra, e seu trabalho permaneceu inacabado.

Não acredito serem exaustivas as recentes iniciativas de proporcionar registros da história que indicam percepções exclusivamente cognitivas de onde estamos e para onde vamos. O lluminismo e seus pressupostos e promessas liberais nutriram boa parte de nossa vida intelectual e nossos debates acadêmicos. No entanto, a modernidade segue sendo submetida a rupturas e desastres, especialmente aqueles infligidos por seres humanos sobre outros, seja intencionalmente ou através das "consequências imprevistas de ações deliberadas". Não está totalmente fora de questão que algum desastre global - natural e/ou tecnológico - venha a reduzir nossa civilização globalizada a sociedades destroçadas de caçadores e coletores, não muito diferentes daquelas dos Arunta e dos Kalapalo. Talvez haja ainda mais necessidade de tomar essas civilizações e também As Formas Elementares como um manual de sobrevivência futura. Para conluir com a problemática de Durkheim: como seria a religião dessa sociedade?

Edward Tiryakian é Professor Emérito de Sociologia, no Trinity College of Arts \& Sciences, Duke University, Durham, NC, Estados Unidos da América. $\triangle$ durkhm@soc.duke.edu 
Sociologias, Porto Alegre, ano 19,no 44, jan/abr 2017, p. 38-71

\section{Referências}

1. ALLEN, N.J. Effervescence and the Origins of Human Society. In: ALLEN, N.J.; PICKERING, W.S.F.; MILLER, W.W. On Durkheim's Elementary Forms of Religious Life. London and New York: Routledge, 1998., pp. 149-61.

2. BASSO, E. Kalapalo. Música e Rituais [online]. In: Povos Indígenas no Brasil. Junho, 2002. Disponível em: (http://pib.socioambiental.org/en/povo/kalapalo)

3. BELLAH, R.N. Religion in Human Evolution. From the Paleolithic to the Axial Age. Cambridge, MA and London: The Belknap Press of Harvard University Press, 2011.

4. BELLAH, R.N.; JOAS, H. The Axial Age and its Consequences. Cambridge, MA and London: The Belknap Press of Harvard University Press, 2012.

5. CHAVES, M. American Religion. Contemporary Trends. Princeton: Princeton University Press, 2011.

6. DURKHEIM, É. The Division of Labor in Society. New York: Free Press, 1997 [1893].

7. DURKHEIM, É. The Elementary Forms of the Religious Life. Translated by Karen E. Fields, New York: The Free Press, 1995 [1912]

8. DURKHEIM, É. Individualism and the Intellectuals [1898]. In: BELLAH, R. (Ed.) Emile Durkheim on Morality and Society. Chicago: University of Chicago Press, 1973, pp. 43-57.

9. DURKHEIM, É. The Dualism of Human Nature and its Social Conditions [1914]. In: BELLAH, R. (Ed.) Emile Durkheim on Morality and Society. Chicago: University of Chicago Press, 1973, pp. 149-163.

10. DURKHEIM, É. Suicide: A Study in Sociology. Translated by John A. Spaulding \& George Simpson. New York: The Free Press of Glenco, 1951 [1897].

11. DURKHEIM, É. Contribution to discussion: 'Sur la séparation des églises et de I'État. In: Libres entretiens, 1st series, 1905, pp. 369-71, 496-500.

12. FOURNIER, M. Marcel Mauss, a Biography [1994]. Trad. Jane Marie Todd, Princeton: Princeton University Press, 2006.

13. FREUD, S. Totem and Taboo. Resemblance between the Psychic Lives of Savages and Neurotics [1912-1913]. Com um novo prefácio de Robert Kenny. Greentop, Missouri: Greentop Academic Press, 2011.

14. HABERMAS, J. Introduction. In: HABERMAS, J. (Ed.) Observations on 'The Spiritual Situation of the Age' [1979]. Cambridge, MA: MIT Press, 1987, pp. 1-28. 
15. HECHT, J.M. The End of the Soul: Scientific Modernity, Atheism, and Anthropology in France. New York: Columbia University Press, 2003, p. 1.

16. JOAS, H. The Axial Age Debate as Religious Discourse. In: BELLAH, R.; JOAS, $\mathrm{H}$. (Eds) The Axial Age and its Consequences. Cambridge, MA and London: The Belknap Press of Harvard University Press, 2012, pp. 9-29.

17. JONES, R.A. On Understanding a Classic. American Journal of Sociology, 83, 2, September 1977, pp. 279-319.

18. JUNG, C. Jung contra Freud: The 1912 New York Lectures on the Theory of Psychoanalysis. Princeton: Princeton University Press, 2012.

19. JUNG, C. Psychology of the Unconscious: a study of the transformations and symbolisms of the libido: a contribution to the history of the evolution of thought. Bollingen Series, 20. Princeton: Princeton University Press, 2001

20. KELLY, T. Igor Stravinsky's 'The Rite of Spring'. NPR Online. NPR's performance today. s/d. Disponível em: http://www.npr.org/programs/specials/milestones/991110.motm.riteofspring.html. Acesso em: 20.12.2016

21. LÖWY, M.; VARIKAS, E. Max Weber et I'anthropologie. L'Année Sociologique, 62, 1, 2012, pp. 123-141.

22. LUKES, S. Emile Durkheim, His Life and Work. A Historical and Critical Study. New York: Harper \& Row, 1972.

23. MAUSS, M. Les techniques du corps. Journal de Psychologie Normale et Pathologique, 32, 1935, pp. 363-386.

24. MENGER, P.-M. L'art, les pouvoirs de l'imagination et l'économie des désires dans la théorie durkheimienne. Durkheimian Studies/Etudes Durkheimiennes, New Series, v.6, 2000, pp. 61-84

25. O'TOOLE, R. Durkheim and the problem of art: some observations. Durkheimian Studies/Etudes Durkheimiennes. New Series, v. 8, 2002, pp. 51-69.

26. OTTO, R. The Holy: On the Irrational in the Idea of the Divine and its Relation to the Rational. Oxford University Press, 1923.

27. PICKERING, W.S.F. Durkheim, the arts and the moral sword. Durkheimian Studies/Etudes Durkheimiennes, New Series, v. 6, 2000, pp. 43-60.

28. PICKERING, W.S.F. The Response of Catholic and Protestant Thinkers to the Work of Emile Durkheim With Special Reference to Les formes élémentaires. Durkheimian Studies, v. 14, 2008, pp. 59-93.

29. PUTNAM, R.D.; CAMPBELL, D.E. American Grace. How Religion Divides and Unites Us. New York: Simon \& Schuster, 2010. 
30. RAMP, W. Effervescence, Differentiation and Representation in The Elementary Forms. In: ALLEN, N.J.; PICKERING, W.S.F.; MILLER, W.W. On Durkheim's Elementary Forms of Religious Life. London and New York: Routledge, 1998, pp. 135-48.

31. SMITH, C. (Ed.). Future Directions in the Sociology of Religion. Social Forces, v.86, n.4, June, 2008, pp. 1561-1589.

32. SMITH, C. What is a Person? Rethinking Humanity, Social Life, and the Moral Good from the Person Up. Chicago: The University of Chicago Press, 2010.

33. SMITH, W.R. Lectures on the Religion of the Semites [1894]. New Brunswick, NJ: Transaction 2002.

34. SPENCER, B.; GILLEN, F.J. Across Australia. London: MacMillan, 1912.

35. SPENCER, B. Native Tribes of the Northern Territory of Australia. London: MacMillan, 1914.

36. TIRYAKIAN, E.A. For Durkheim: Essays in Comparative and Historical Sociology. Burlington: Ashgate Publishing, 2009

37. TIRYAKIAN, E.A. Time to Change the Calendar? Sacred and Secular Problems of Crossing the Millennium. International Review of Sociology/Revue Internationale de Sociologie, 11, 3, November 2001, pp. 419-29.

38. TIRYAKIAN, E.A. Durkheim, Mathiez, and the French Revolution. The political context of a sociological classic. European Journal of Sociology, 29, 1988, pp. 373-396.

39. TROELTSCH, E. The Social Teaching of the Christian Churches. 2 vols. Trad. de Olive Wyon. New York: Macmillan, 1931.

40. TURNER, D.H. Afterlife Before Genesis. An Introduction: Accessing the Eternal Through Australian Aboriginal Music. New York: Peter Lang, 1997.

Recebido: 28.09.16

Aceito: 26.12 .16 